\title{
Net Ecosystem Production of a River Relying on Hydrology, Hydrodynamics and Water Quality Monitoring Stations
}

\author{
Fernando Rojano $^{1, *}$, David H Huber ${ }^{1,2}$, Ifeoma R Ugwuanyi ${ }^{2}\left(\mathbb{D}\right.$, Vadesse Lhilhi Noundou ${ }^{2}$, \\ Andrielle Larissa Kemajou-Tchamba ${ }^{2}$ and Jesus E Chavarria-Palma ${ }^{1,2}$ \\ 1 Gus R. Douglass Institute, West Virginia State University, Institute, WV 25112, USA; \\ huberdh@wvstateu.edu (D.H.H.); jchavarriap@wvstateu.edu (J.E.C.-P.) \\ 2 Department of Biology, West Virginia State University, Institute, WV 25112, USA; \\ iru1@scarletmail.rutgers.edu (I.R.U.); vadln@udel.edu (V.L.N.); akemajoutchamba@wvstateu.edu (A.L.K.-T.) \\ * Correspondence: fernando.rojano@wvstateu.edu
}

Received: 27 January 2020; Accepted: 8 March 2020; Published: 12 March 2020

check for updates

\begin{abstract}
Flow and water quality of rivers are highly dynamic. Water quantity and quality are subjected to simultaneous physical, chemical and biological processes making it difficult to accurately assess lotic ecosystems. Our study investigated net ecosystem production (NEP) relying on high-frequency data of hydrology, hydrodynamics and water quality. The Kanawha River, West Virginia was investigated along $52.8 \mathrm{~km}$ to estimate NEP. Water quality data were collected along the river using three distributed multiprobe sondes that measured water temperature, dissolved oxygen, dissolved oxygen saturation, specific conductance, turbidity and ORP hourly for 71 days. Flows along the river were predicted by means of the hydrologic and hydrodynamic models in Hydrologic Simulation Program in Fortran (HSPF). It was found that urban local inflows were correlated with NEP. However, under hypoxic conditions, local inflows were correlated with specific conductance. Thus, our approach represents an effort for the systematic integration of data derived from models and field measurements with the aim of providing an improved assessment of lotic ecosystems.
\end{abstract}

Keywords: basin; hydrologic model; reaeration rates; stream metabolism; watershed

\section{Introduction}

Physicochemical and hydro-morphological properties of a river combined with biological communities [1,2] cause simultaneous physical, chemical and biological processes. Consequently, spatiotemporal variation is under an endless search for equilibrium by means of interactions between biotic and abiotic factors [3,4]. Those interactions can be assessed using the net ecosystem production (NEP) [5], which has been successfully applied to rivers for several decades [6]. NEP is the combined representation of gross primary production and ecosystem respiration. However, NEP must balance reaeration rates with photosynthetic production, respiratory consumption and all processes that can cause changes to dissolved oxygen [7-9]. Among the complex interaction of nutrients, biomass and trophic structure, NEP can be used, for example, as a means to explain carbon fluxes $[10,11]$, given the potential of rivers to store, mineralize and transport carbon to coastal areas [9]. To accurately estimate NEP, data associated with flow and water quality must be reliable [12]. Nonetheless, different deployed instruments are needed. To succeed in an analysis over time and space, our study alternatively proposes the use of models to estimate flow as an adequate approach to reduce instrumentation. It also proposes an integration of hydrologic and hydrodynamic models with water quality data which can also be implemented as an automated procedure to estimate NEP. 
Development, calibration and validation of a hydrologic model to represent a drainage area along a river within the spatiotemporal domain must consider phenomena such as infiltration, evaporation and streamflow [13-15]. The hydrologic model took account of information about land use and topography specifications to handle hydro-climatic conditions in order to determine streamflow [16]. Consequently, streamflow can be coupled to a hydrodynamic model to predict flow along the river. In our study, the hydrologic and hydrodynamic models were implemented in the Hydrologic Simulation Program in Fortran (HSPF). Given that there was a set of unknown parameters governing the HSPF model, our study integrated a process for parameters calibration using the non-sorted genetic algorithm II (NSGA-II) [17,18]. This approach increased reliability under uncertainty of new hydrologic scenarios [19-21] and supported the use of an optimal solution $[20,22,23]$ as the best set of parameters for the HSPF model. To guarantee satisfactory predictions, HSPEXP+ 2.0 was used to assess the calibrated HSPF model, as in the works of Xie et al. [20] and Lampert and $\mathrm{Wu}$ [24]. In this way, the streams module of the HSPF model can provide reliable predictions of the flow and velocity variables at specific locations along the river. Flow and velocity variables were input data to estimate reaeration rates. Nonetheless, an enhanced calculation of reaeration rates can be achieved by means of a set of equations [25] using a standardized Schmidt number $[26,27]$ which was empirically estimated as a function of water temperature $[28,29]$.

To provide an improved assessment of NEP, high-frequency data of water quality is now feasible [30], which seems promising and advantageous with respect to the periodic collection of water samples on a daily or lower frequency. Periodic observations of water quality at high-frequency could incorporate all processes such as cycles of nutrients (e.g., nitrogen, phosphorous), dissolved oxygen balance, sorption/desorption, volatilization, ionization, oxidation, biodegradation, hydrolysis and photolysis [31]. As result of all these processes, dissolved oxygen has been given special attention because it is the key variable for estimating NEP [32]. Dissolved oxygen is also closely related to water mixing, gas exchanges at the air-water interface, water temperature, flow, velocity and irradiance [27]. In addition, dissolved oxygen is subjected to spatial variability according to specifications of land use and local inflows [33-37]. Therefore, our study uses high-frequency data at various locations along the river as a way to contribute to the analysis of spatiotemporal impact of physicochemical properties of water on NEP.

This study was conducted within the Appalachian Region which is subjected to various water related stressors such as mining, urban settlements and industry. The Kanawha River, West Virginia, was chosen because it merges multiple inflows along the river at different rates and locations, disturbing water quantity and quality. Those inflows include tributaries, creeks, combined sewer overflows (CSO) and national pollutant discharge elimination system (NPDES). Therefore, NEP can be used as a proxy to assess those stressors and also to depict their variability over time and space.

In our study, hydrologic and hydrodynamic models and water quality data were integrated using a series of steps to estimate NEP under a high-frequency approach. Those steps were defined in this research as follows: (1) implementing a hydrologic model for drainage area along the river; (2) linking a hydrologic model with a hydrodynamic model; (3) collecting data about water temperature, dissolved oxygen and dissolved oxygen saturation, specific conductance, turbidity and ORP using monitoring stations installed along the river; (4) analyzing NEP under a spatiotemporal approach; and (5) assessing the impact of water quality on NEP and local inflows.

\section{Materials and Methods}

\subsection{Watershed Description}

The study area within the Appalachian Region was defined by $2995 \mathrm{~km}^{2}$ draining water along the Kanawha River located in West Virginia, USA. Elk, Coal and Pocatalico Rivers (Figure 1) are tributaries of the Kanawha River; these rivers delimited the drainage area at the location of the flow gages F2, F4 and F5, respectively. The Kanawha River had F1 and F3 flow gages located at the upstream and center of the study area. Locations for the five flow gages are provided in Table 1. Along the Kanawha River, 
the start and end limits were defined at the highest and lowest elevation of $190 \mathrm{~m}\left(38.1381^{\circ} \mathrm{N}, 81.2144^{\circ}\right.$ $\mathrm{W})$ and $172 \mathrm{~m}\left(38.4828^{\circ} \mathrm{N}, 81.8258^{\circ} \mathrm{W}\right)$ above sea level, respectively.

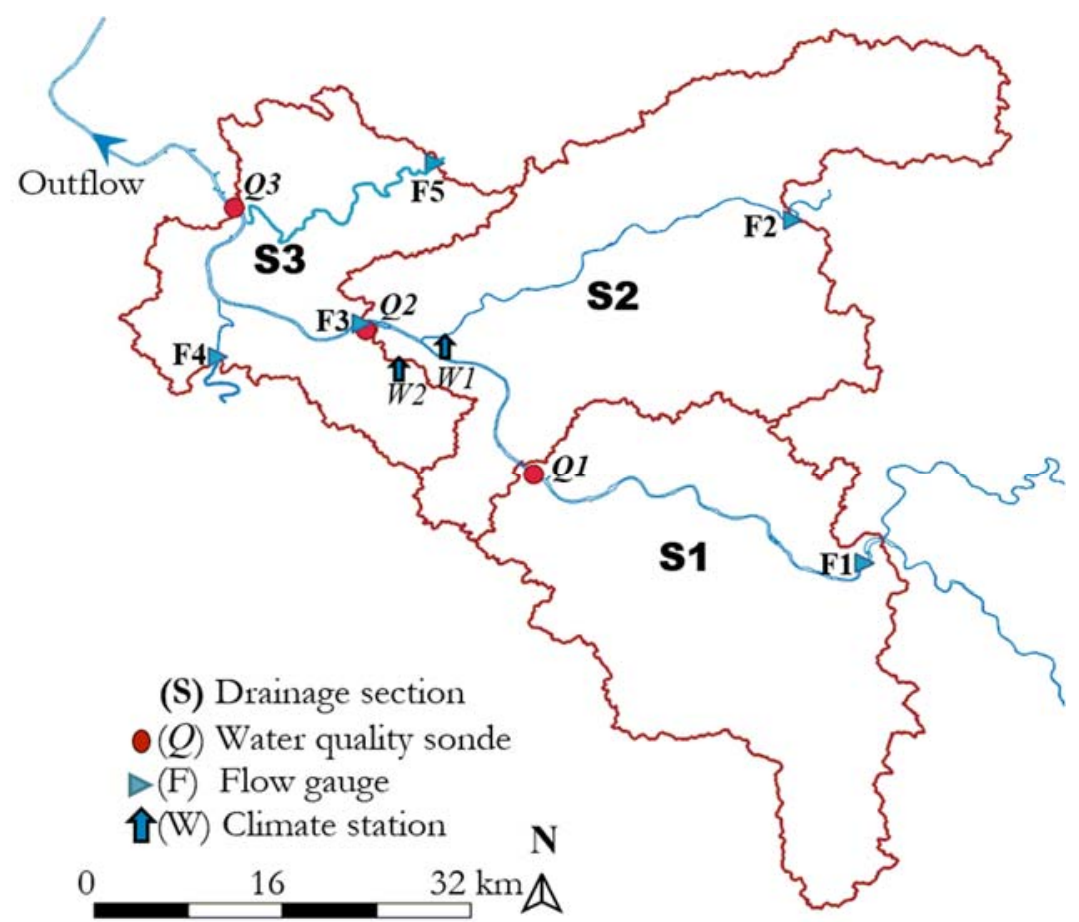

(a)

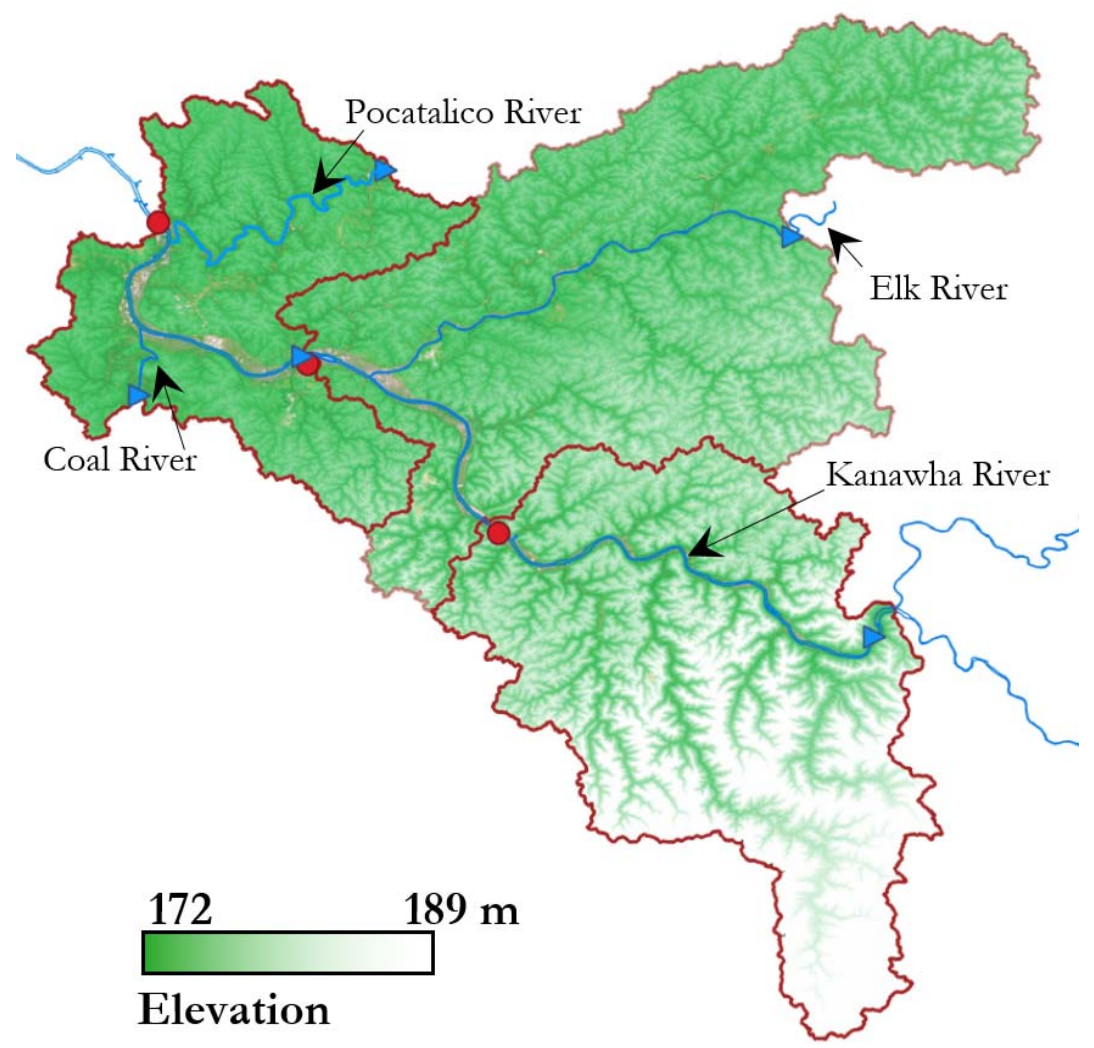

(b)

Figure 1. Description of (a) the study area and (b) drainage area of the Kanawha River, West Virginia, which were delimited by flow gages and water quality monitoring stations specified in Table 1. 
Table 1. Location of flow gages, weather stations and water quality sondes indicated in Figure 1.

\begin{tabular}{ccccc}
\hline \multirow{5}{*}{ Flow gage } & & Latitude (N) & Longitude (W) & Elevation (m) \\
\hline & F1 & $38.1381^{\circ}$ & $81.2144^{\circ}$ & 190 \\
& F2 & $38.4714^{\circ}$ & $81.2839^{\circ}$ & 186 \\
& F3 & $38.3714^{\circ}$ & $81.7022^{\circ}$ & 173 \\
& F4 & $38.3389^{\circ}$ & $81.8412^{\circ}$ & 177 \\
& F5 & $38.5261^{\circ}$ & $81.6310^{\circ}$ & 183 \\
\hline \multirow{2}{*}{ Weather stations } & W1 & $38.3794^{\circ}$ & $81.5900^{\circ}$ & 279 \\
& W2 & $38.3131^{\circ}$ & $81.7192^{\circ}$ & 277 \\
\hline \multirow{5}{*}{ Water quality } & Q1 & $38.2244^{\circ}$ & $81.5356^{\circ}$ & 181 \\
sondes & Q2a & $38.3638^{\circ}$ & $81.6630^{\circ}$ & 173 \\
& Q2b & $38.3625^{\circ}$ & $81.6642^{\circ}$ & 173 \\
& Q2c & $38.3625^{\circ}$ & $81.6642^{\circ}$ & 170.5 \\
& Q3 & $38.4828^{\circ}$ & $81.8258^{\circ}$ & 172 \\
\hline
\end{tabular}

Land topography is predominantly hilly dissected terrain. It contains forest, urban, barren and agricultural land representing $86 \%, 5.7 \%, 4.8 \%$ and $3 \%$, respectively, where barren land was mainly characterized by mining activities, and the rest of the study area was dedicated to wetland. A detailed description of land use is shown in Table 2. Hourly discharge at start of the Kanawha River (F1) had minimum, average and maximum flows of $35.1,387.2$ and $3645 \mathrm{~m}^{3} / \mathrm{s}$, respectively, during a period of observation of 913 days. The study area along the Kanawha River started with drainage areas at $\mathrm{F} 1$ and F2 of 21,680.8 and $2965.5 \mathrm{~km}^{2}$, respectively. Inflows of tributaries at F4 and F5 comprised drainage areas of 2232.6 and $616.4 \mathrm{~km}^{2}$, respectively. The study area (S1, S2 and S3) was focused on $2995 \mathrm{~km}^{2}$, which was bounded by the locations along the Kanawha River of the first flow gage (F1) and three sondes (Q1, Q2 and Q3). This study area provided conditions to conduct an analysis of the flow dynamics and impact of local inflows on water quality.

Table 2. General description of land use for study area indicated in Figure 1.

\begin{tabular}{ccccc}
\hline & & $\left.\mathbf{S 1} \mathbf{( k m}^{\mathbf{2}}\right)$ & $\left.\mathbf{S 2} \mathbf{( k m}^{\mathbf{2}}\right)$ & $\left.\mathbf{S 3} \mathbf{( k m}^{\mathbf{2}}\right)$ \\
\hline \multirow{4}{*}{ Land Use } & Urban & 33.33 & 88.32 & 49.1 \\
& Agriculture & 14.68 & 39.6 & 36.34 \\
& Forest & 899.7 & 1307 & 359.83 \\
& Wetland & 9.5 & 7.69 & 5.18 \\
& Barren & 131.75 & 11.11 & 1.71 \\
\hline
\end{tabular}

The study area was characterized by annual average minimum and maximum dry bulb temperatures of 6.7 and $18.9{ }^{\circ} \mathrm{C}$, respectively, an annual average precipitation of $1107 \mathrm{~mm}$, and an annual average snowfall of $838 \mathrm{~mm}$. Snow counted as precipitation, which was melted following the heat balance approach relying on precipitation, air temperature, solar radiation, wind velocity and dew point [13]. Climate data about precipitation, dry and dew point temperatures and wind speed were provided by two weather stations (Figure 1). Solar radiation was not available in the two weather stations, so it was retrieved as an average for the study area from the national solar radiation database [38].

\subsection{HSPF Model Description}

The HSPF model was used for predicting flows of a watershed that joins modeling of watersheds and streams [39-41]. In addition, the HSPF model can be used to incorporate the transport of pollutants and nutrients. Information about land use, topography and climate assisted in the estimation of flow in streams (Table 3) that follows a hydrodynamic pattern according to the terrain slope. Before water arrives at the streams, there are regular paths of water flow within the watershed which can be summarized in Figure 2. For instance, after rainfall there is an immediate interception by the canopy 
(CEPSC). The remaining water enters soil, which has a capacity to infiltrate and store within the upper zone (UZS) and lower zone (LZS). The excess of water could continue to reach active groundwater (AGWS) and base flow (BASETP) or enter deeper aquifers.

Table 3. Mainstream and tributaries specifications.

\begin{tabular}{cccccc}
\hline $\begin{array}{c}\text { Drainage } \\
\text { Section }\end{array}$ & Stream & $\begin{array}{c}\text { Length, } \\
\mathbf{k m}\end{array}$ & $\begin{array}{c}\text { Elevation } \\
\text { Change, } \mathbf{m}\end{array}$ & $\begin{array}{c}\text { Average } \\
\text { Slope, m }\end{array}$ & $\begin{array}{c}\text { Average } \\
\text { Width, m }\end{array}$ \\
\hline 1 & Kanawha River & 38.5 & $9^{*}$ & 0.00005 & 183 \\
2 & Kanawha River & 23.5 & $7.8^{*}$ & 0.00004 & 183 \\
& Elk River & 41.5 & 13 & 0.00031 & 76 \\
3 & Kanawha River & 29.3 & 0.61 & 0.00003 & 183 \\
& Coal River & 18.7 & 4.57 & 0.00024 & 52 \\
& Pocatalico River & 41 & 10.4 & 0.00025 & 31 \\
\hline
\end{tabular}

* Includes a dam with an average level change of $7.1 \mathrm{~m}$.

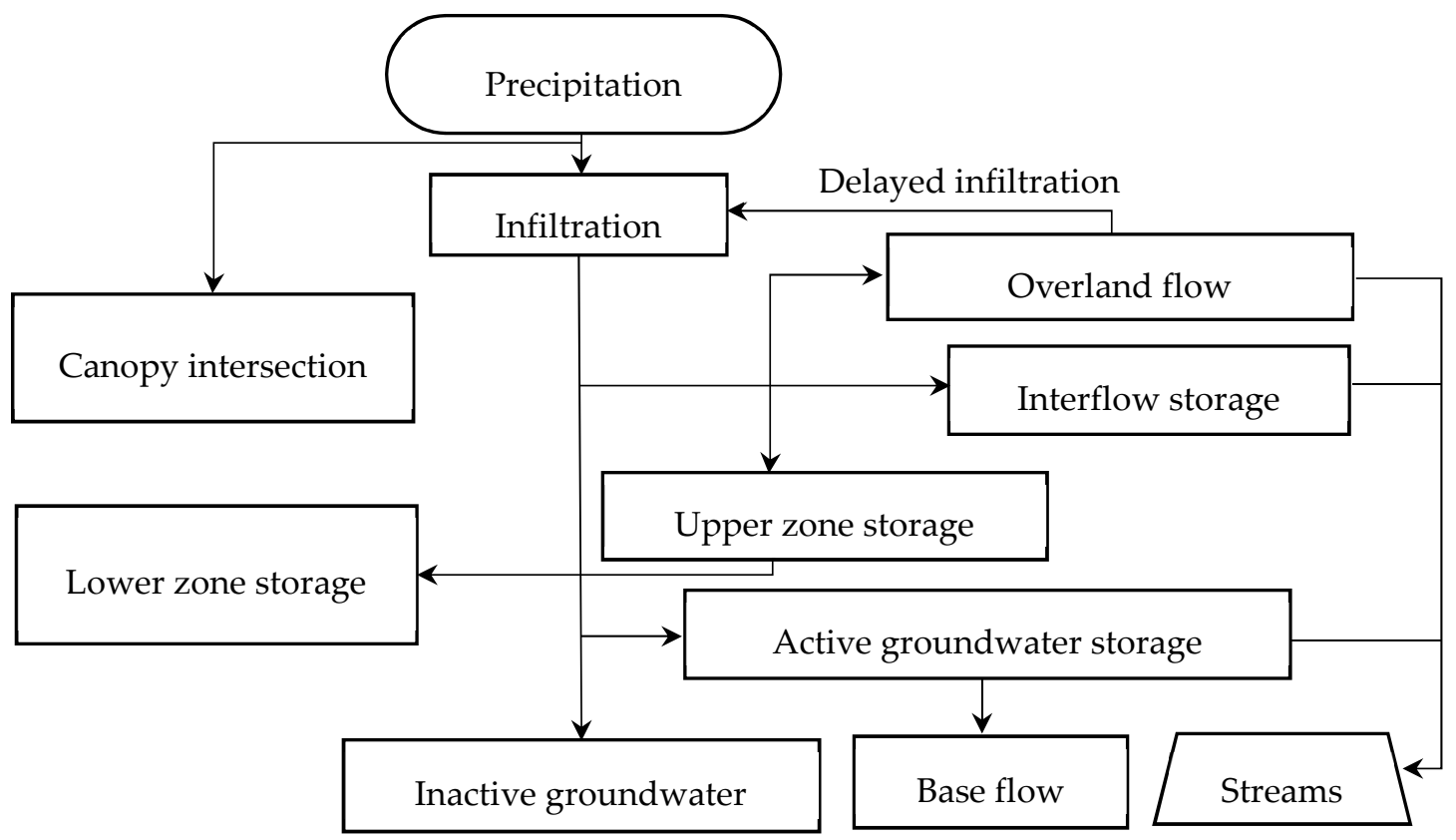

Any stage subjected to evaporation

Figure 2. Water paths and storages within a watershed occurring in the pervious land used in the HSPF model.

Concurrently, all of the watershed is subjected to evapotranspiration, where rates depend mostly on solar radiation, air temperature and humidity, whereas underground water is subjected only to evaporation. Each stage follows specific equations to determine flow rates which are defined by a set of parameters according to specifications of the watershed such as average slope (SLSUR) and mean elevation (MLS). Other parameters must be found during a process of adjustment such as groundwater recession flow (KVARY) and infiltration (INFILT). Descriptions of all parameters in the HSPF model are shown in Table 4, where seven values were deduced from the input data related to land use and topography and thirteen parameters must be calibrated in order to reduce error in flow predictions.

Modeling of streams relied on input data from inflows, river network configuration and a one dimensional approach of the river under a fully advective flow. The one dimensional approach required a homogeneous river transect, a representative Manning's coefficient (equal to 0.1) and a slope excluding dam elevation. Then, drainage sections with their corresponding streams were used to generate a HPSF model that was able to predict average flow and water velocity of streams. The governing equations used within the frame of a HSPF model can be found in Duda et al. [13]. 
Table 4. Parameters required to build up a Hydrologic Simulation Program in Fortran (HSPF) model.

\begin{tabular}{|c|c|c|c|}
\hline Parameter & Units & Meaning & $\begin{array}{l}\text { Range or } \\
\text { Averaged } \\
\text { Data }\end{array}$ \\
\hline LZSN & $(\mathrm{mm})$ & Lower zone nominal storage & $51-381$ \\
\hline INFILT & $(\mathrm{mm} / \mathrm{h})$ & Index to soil infiltration capacity & $0.02-13$ \\
\hline LSUR & $(\mathrm{m})$ & Average length of the assumed overland flow plane & $69.2 *$ \\
\hline SLSUR & $(-)$ & Average slope of the overland flow plane & $0.107 *$ \\
\hline KVARY & $(1 / \mathrm{mm})$ & Variable groundwater recession flow & $0-0.2$ \\
\hline AGWRC & (1/day) & Basic groundwater recession rate & $0.85-0.99$ \\
\hline PETMAX & $\left({ }^{\circ} \mathrm{C}\right)$ & $\begin{array}{l}\text { Air temperature below which evapotranspiration (ET) will } \\
\text { arbitrarily be reduced below the value obtained from the } \\
\text { input time series }\end{array}$ & $4.4^{*}$ \\
\hline PETMIN & $\left({ }^{\circ} \mathrm{C}\right)$ & $\begin{array}{c}\text { Temperature below which E-T will be zero regardless of } \\
\text { the value in the input time series }\end{array}$ & 1.7 * \\
\hline INFEXP & $(-)$ & Exponent in the infiltration equation & $2 * *$ \\
\hline DEEPFR & $(-)$ & $\begin{array}{l}\text { Fraction of groundwater inflow which will enter deep } \\
\text { (inactive) groundwater }\end{array}$ & $0-0.5$ \\
\hline BASETP & $(-)$ & Base flow evapotranspiration & $0-0.2$ \\
\hline AGWETP & $(-)$ & $\begin{array}{l}\text { Fraction of remaining potential E-T which can be satisfied } \\
\text { from active groundwater storage }\end{array}$ & $0-0.2$ \\
\hline CEPSC & $(\mathrm{mm})$ & Interception storage capacity & $0-10$ \\
\hline UZSN & $(\mathrm{mm})$ & Upper zone nominal storage & $1-51$ \\
\hline NSUR & $(-)$ & Manning's $\mathrm{n}$ for overland flow & $0.1-0.5$ \\
\hline INTFW & $(-)$ & Interflow inflow parameter & $1-10$ \\
\hline IRC & (1/day) & Interflow recession constant & $0.3-0.85$ \\
\hline LZETP & $(-)$ & $\begin{array}{l}\text { Lower zone E-T parameter. It is an index to the density of } \\
\text { deep-rooted vegetation. }\end{array}$ & $0-0.9$ \\
\hline LAT & $\left({ }^{\circ}\right)$ & Latitude of the pervious land segment (PLS) & $38 *$ \\
\hline MELEV & (m) & Mean elevation of the PLS & $181 *$ \\
\hline
\end{tabular}

* Average value was deduced from the watershed data in BASINS 4.1. ${ }^{* *}$ Value recommended by [13].

\subsection{Multiobjective Calibration of the HSPF Parameters}

Among the various tools available in the search for adequate parameters defining the water dynamics of the HSPF model, we chose NSGA-II to look at the solution of two optimized objectives. The procedure to implement NSGA-II in MATLAB consisted of an iterative evaluation of different scenarios of the hydrologic model. Different scenarios were obtained using initial random values within the range stated in Table 3 regarding the parameters LZSN, INFILT, KVARY, AGWRC, DEEPFR, BASETP, AGWETP, CEPSC, UZSN, INTFW, IRC, LZETP and NSUR. The iterative evaluation was accomplished for 400 sets of parameters that were evaluated in the HSPF model (Figure 3). The next generation was deduced by creating 400 new sets of parameters that had a crossover and mutation probability of 0.9 and 0.1 , respectively. The NSGA-II considered 1000 generations to define final calibrated values of the 13 parameters. To identify the best set of solutions, NSGA-II implemented two objectives: Nash-Sutcliffe model efficiency (NSE) and the percent bias coefficient (PBIAS) as the criteria to evaluate the error between flow measurements and HSPF model flow predictions. Identification of the optimal solution was accomplished by means of the Pareto front, which has the best solution when the magnitude is minimum for NSE [42] and PBIAS [43]. 


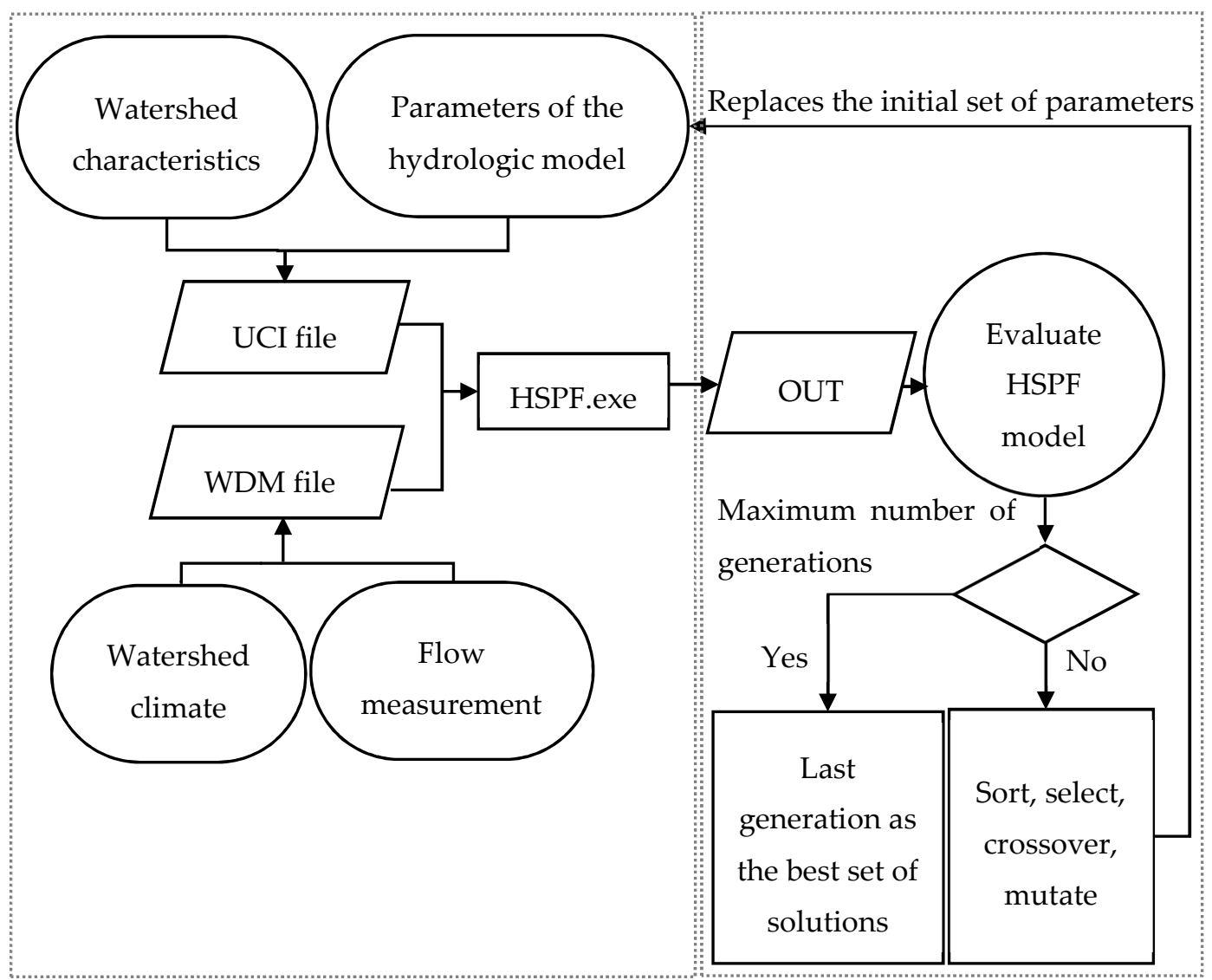

Figure 3. Relation between the HSPF model and non-sorted genetic algorithm II (NSGA-II) to find the best optimal solution.

\subsection{Field Measurements of Water Quality}

The high-frequency monitoring system consisted of three Eureka Manta 2 multiprobe sondes. Each sonde measured water temperature $\left( \pm 0.1^{\circ} \mathrm{C}\right)$, dissolved oxygen $( \pm 0.2 \mathrm{mg} / \mathrm{L})$, dissolved oxygen saturation $( \pm 1 \%)$, specific conductance ( \pm 1 of reading), turbidity ( $\pm 3 \%$ of reading) and oxidative-reductive potential $( \pm 20 \mathrm{mV})$ with a time step of $1 \mathrm{~h}$. Three locations along the river indicated in Figure 1, defined by Q1, Q2 and Q3, were monitored. That configuration facilitated our estimate of water quality changes as water moved downstream. Differences of sensor measurements served to further assess impact of local inflows comprising point and nonpoint sources of water pollution due to drained water along the river.

\subsection{Net Ecosystem Production}

NEP provides an assessment of rivers that encompasses physical and chemical characteristics. Physical characteristics include slope, width, depth and flow together with chemical characteristics such as nutrients, organic matter and water chemistry. In addition, other factors can be intrinsically intervening in NEP dynamics such as the effects of dams, riparian vegetation and pollution. NEP can also be seen as the balance of autotrophic and heterotrophic elements of the river [7]. Specifically, NEP can be evaluated through Equation (1) of Odum, 1956 [5].

$$
\frac{d O}{d t}=\mathrm{NEP}+k\left(C_{s}-C\right)+P
$$

where NEP is the gross primary production minus ecosystem respiration. $k$ is oxygen reaeration coefficient. $C_{S}$ is dissolved oxygen saturation and $C$ is dissolved oxygen observed. $P$ is the drainage 
accrual and accounts for all processes happening in the river together with dissolved oxygen of local inflows. Some of those processes include horizontal and vertical advection, photochemical oxidation of organic matter and nonaerobic consumption of oxygen during the time step of observation [7].

Estimation of the $k$ value was determined by means of $k_{600}$ (Equation (2)) which can be obtained by using one of three candidate Equations (4)-(6) and the Schmidt number. According to Raymond et al. [25], those three equations had the best fit with respect to field measurements. Those three equations also relied on the Schmidt number (Equation (3)) to estimate the mass transfer rates under momentum. The Schmidt number is the ratio of kinematic viscosity to the diffusion coefficient, which in turn can be determined as a function of temperature.

$$
\begin{gathered}
k_{600}=\left(\frac{600}{S c}\right)^{-0.5} \times k \\
S c=A+B T+C T^{2}+D T^{3} \\
k_{600}=5037 \times(V S)^{0.89} \times H^{0.54} \\
k_{600}=5937\left(1-2.54 F r^{2}\right) \times(V S)^{0.54} \times H^{0.58} \\
F r=V / \sqrt{g H} \\
k_{600}=4725 \times(V S)^{0.86} \times Q^{-0.14} \times H^{0.66}
\end{gathered}
$$

where $V$ is water velocity, $S$ is slope and $H$ is depth of the river. $g$ is the gravity force. $S c$ is the Schmidt number and $T$ is temperature. $F r$ is the Froude number. Constant values are $A=1568, B=-86.04, C=$ 2.142 and $D=-0.0216$ [25].

\section{Results and Discussion}

\subsection{Input Data and Calibration}

Data for all flow gages and climate stations were retrieved for the period from 1 October 2015 to 31 March 2018. To match all data, a common time step of one hour was adopted for all variables. Data from two climate stations were averaged instead of segmenting the watershed according to the area of influence, since both stations were in proximity. An example of average precipitation is shown in Figure 4. It should be noted that peaks related to precipitation might not coincide with peaks on measurements of flow gages due to local inflows of tributaries to the Kanawha River. The estimation of evapotranspiration rates was deduced by following the Turc method [44] and adding this data to the HSPF model. Climate data used in this model were compared by means of coefficient of variation (CV) with NASA data sources (i.e., NLDAS and AIRS) in daily time step for precipitation, temperature, dew-point temperature and evapotranspiration; results are presented in Table 5. Data of flow gages originally obtained with a time step of 15 minutes were converted to a $1 \mathrm{~h}$ time step using a moving average filter.

Table 5. Average daily data comparison between NASA data sources and climate station.

\begin{tabular}{cccccccccc}
\hline & $\begin{array}{c}\text { Precipitation, } \\
\text { mm }\end{array}$ & \multicolumn{2}{c}{ Temperature, ${ }^{\circ} \mathbf{C}$} & \multicolumn{2}{c}{$\begin{array}{c}\text { Dew Point } \\
\text { Temperature }{ }^{\mathbf{1}},{ }^{\circ} \mathbf{C}\end{array}$} & $\begin{array}{c}\text { Evapotranspiration (EVT), } \\
\text { mm }\end{array}$ \\
\hline Source & Station & NLDAS & Station & NLDAS & Station & $\begin{array}{c}\text { NLDAS } \\
\text { and AIRS }\end{array}$ & Station & NLDAS & $\begin{array}{c}\text { Potential } \\
\text { EVT }\end{array}$ \\
\hline Mean & 2.54 & 2.91 & 12.78 & 12.88 & 7.72 & 10.11 & 0.965 & 1.677 & 4.318 \\
CV & 2.292 & 2.085 & 0.299 & 0.302 & 0.380 & 0.368 & 0.964 & 0.706 & 0.533 \\
\hline
\end{tabular}

${ }^{1}$ Dew point was estimated from average daily temperature (NLDAS) and relative humidity (AIRS) datasets. 


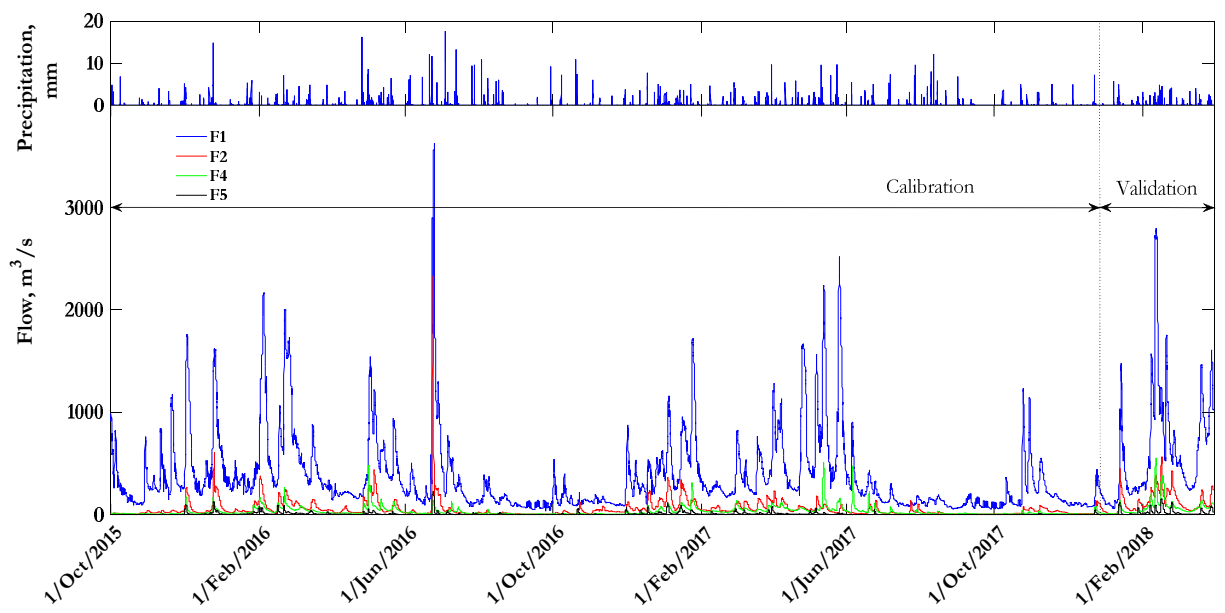

Figure 4. Observed precipitation and flows in the Kanawha River and its tributaries during 1 October 2015 to 31 March 2018.

The calibration of the HSPF model was conducted for $2413 \mathrm{~km}^{2}$, corresponding to S1 and S2 drainage sections. The HSPF model was subjected to an iterative evaluation using the NSGA-II. The best optimal solution was deduced with the minimum Euclidean distance from the origin to the NSE and PBIAS scores. It should be pointed out that NSE and PBIAS were applied to the outflow F3 comprising inflows F1 and F2 together with predicted drained water at S1 and S2. Nonetheless, inflows $\mathrm{F} 1$ and F2 greatly contributed to the outflow predictions, given that the drainage area from F1 and F2 to F3 increased by $10 \%$. This means that drainage changed from $24,646.3$ to $27,060 \mathrm{~km}^{2}$ at the location of gage F3. Such conditions enhanced NSE and PBIAS scores, which were 0.96 and $1.97 \%$, respectively, when comparing predictions and observations from 1 October 2015 to 11 January 2018 in flow gage F3 (Figure 5). NSE and PBIAS scores can be categorized as acceptable [43]; however, those results should be weighed based on the aggregated water between inflow and outflow of the drainage area along the river.

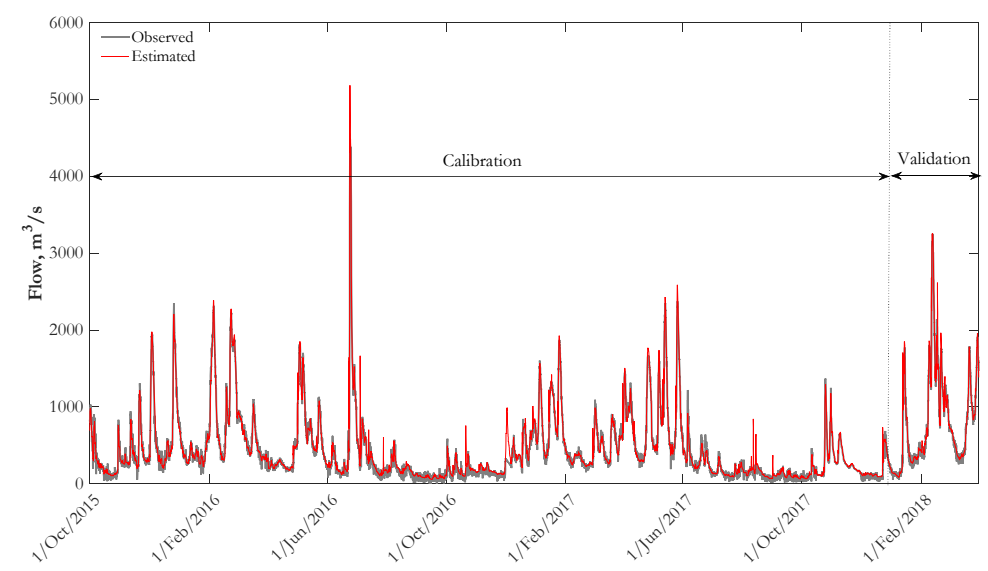

Figure 5. Observed and HPSF predictions of the flows at F3 during the stage of calibration and validation.

To confirm the adequacy of these parameters (Table 6) as the best optimal solution identified by NSGA-II, the calibrated HSPF model was analyzed by means of the HSPEXP+ 2.0 program in order to fulfill overall criteria regarding water balance (Table 7). It was found that error between predictions and measurements increased as the flow decreased; even so, the criteria were satisfied. Subsequently, the HSPF model predicted a water budget that was distributed as follows: $4.3 \%$ to surface flow, $17.9 \%$ to interflow, $32.5 \%$ to base flow and deep aquifers and $45.3 \%$ to evapotranspiration. The rate of evapotranspiration dominated water balance and was driven by BASETP and AGWETP and 
LZETP parameters. Water also accumulated in soil at rates determined by USZN, LZSN and INFILT parameters; however, a significant volume of water moved down to the base flow and deep aquifers.

Table 6. Calibrated parameters of the HSPF model identified by the NSGA-II.

\begin{tabular}{cccc}
\hline Parameter & Value & Parameter & Value \\
\hline LZSN & 51 & CEPSC & 9.7 \\
INFILT & 6.1 & UZSN & 4.4 \\
KVARY & 0.098 & NSUR & 0.109 \\
AGWRC & 0.98 & INTFW & 2.647 \\
DEEPFR & 0.494 & IRC & 0.302 \\
BASETP & 0.198 & LZETP & 0.709 \\
AGWETP & 0.105 & & \\
\hline
\end{tabular}

Table 7. HSPF model performance through HSPEXP+ 2.0.

\begin{tabular}{clc}
\hline \multicolumn{1}{c}{ Measure } & & HSPEXP Limit \\
\hline Error in total volume, \% & 1.71 & 10 \\
Error of highest 10\% flows, \% & -0.21 & 15 \\
Error of highest 25\% flows, \% & -0.49 & 10 \\
Error of highest 50\% flows, \% & -0.03 & 10 \\
Error of lowest 50\% flows, \% & 9.59 & 10 \\
Error of lowest 25\% flows, \% & 13.29 & 15 \\
Error of lowest 10\% flows, \% & 14.72 & 20 \\
\hline
\end{tabular}

Flow estimations using the calibrated HSPF model at the S1 and S2 drainage sections can be considered reliable as they were validated by flow measurements at gage F3. However, flow estimations at the outlet (Q3) of the S3 drainage area entirely relied on the accuracy of the calibrated HSPF model. The HSPF model validation found a significant contribution of the tributaries to the Kanawha River. For instance, from the total amount of water added within the $\mathrm{S} 2$ section, $78 \%$ of the water was contributed by the Elk River based on flow measurements at F2. In the same way, from the total amount of water added within the S3 section, 91\% of the water was contributed by Coal and Pocatalico Rivers, according to measurements at F4 and F5. Flow dynamics at Q1, Q2 and Q3, during the period from 11 January 2018 to 31 March 2018 (Figure 6), were based on the combined effects of inflows and drainage areas along the river. S1, S2 and S3 involved local inflows such as rainfalls, CSO and NPDES. The CV for flow data was computed having $0.77,0.73$ and 0.73 for locations Q1, Q2 and Q3, respectively. These $\mathrm{CV}$ values verified that flow dynamics were similar only in the Q2 and Q3 locations.

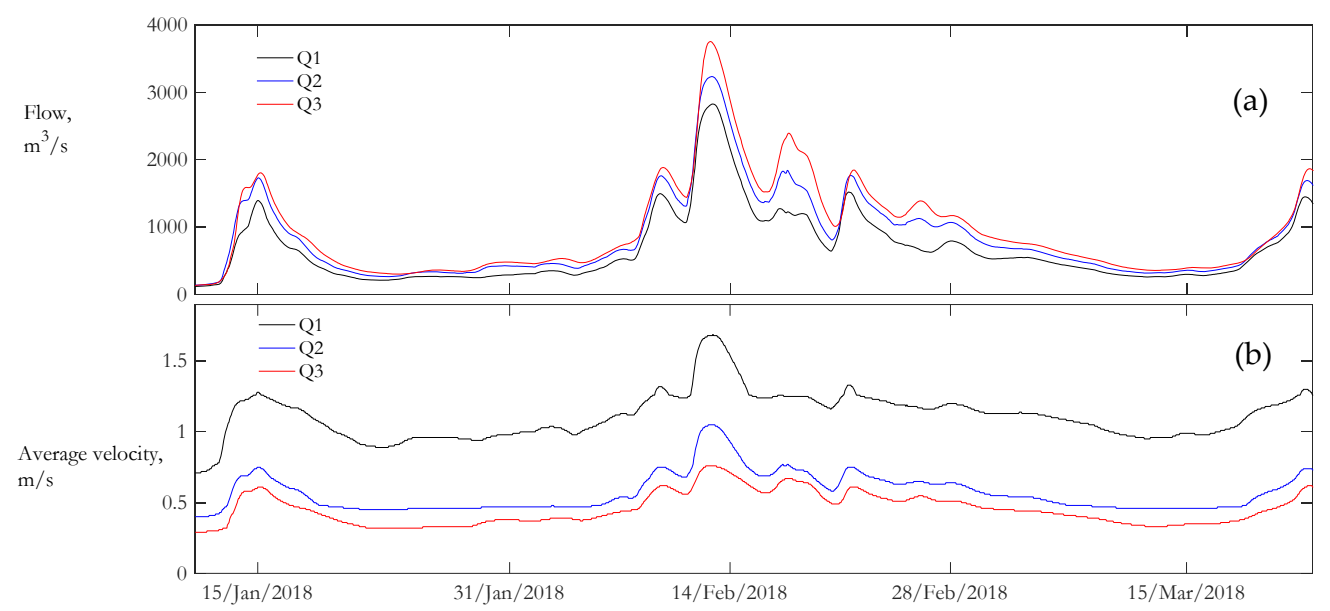

Figure 6. HSPF model predictions about (a) flow and (b) average water velocity at the locations Q1, Q2 and Q3 along the Kanawha River. 


\subsection{Water Quality}

Water quality data were collected for 71 days with a time step of $1 \mathrm{~h}$ covering the period from 11 January 2018 to 22 March 2018 (Supplementary Data). Erroneous readings were discarded. Measurements for the three locations are shown in Figures 7 and 8 and available in Huber et al. [45]. The CV among all sensor readings (Table 8) showed that minimum and maximum scores were for dissolved oxygen saturation and turbidity, respectively. The same type of sensor readings among the three locations also had minimum and maximum differences of the $\mathrm{CV}$ for temperature and dissolved oxygen saturation. In summary, we found that dissolved oxygen saturation had minimum dispersion among all the sensors at the same location and maximum dispersion among the three locations.

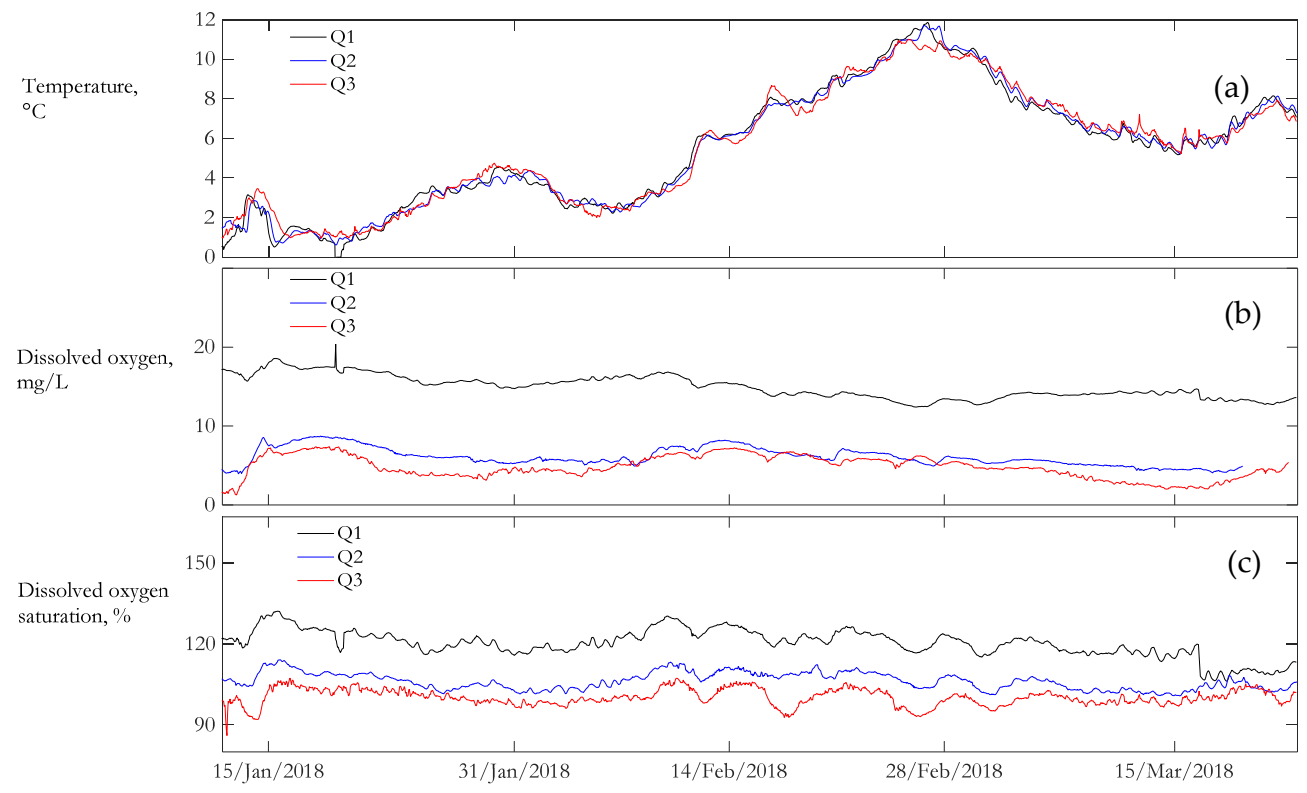

Figure 7. Sensor measurements of (a) temperature, (b) dissolved oxygen and (c) dissolved oxygen saturation at three locations (Q1, Q2 and Q3) of the Kanawha River.

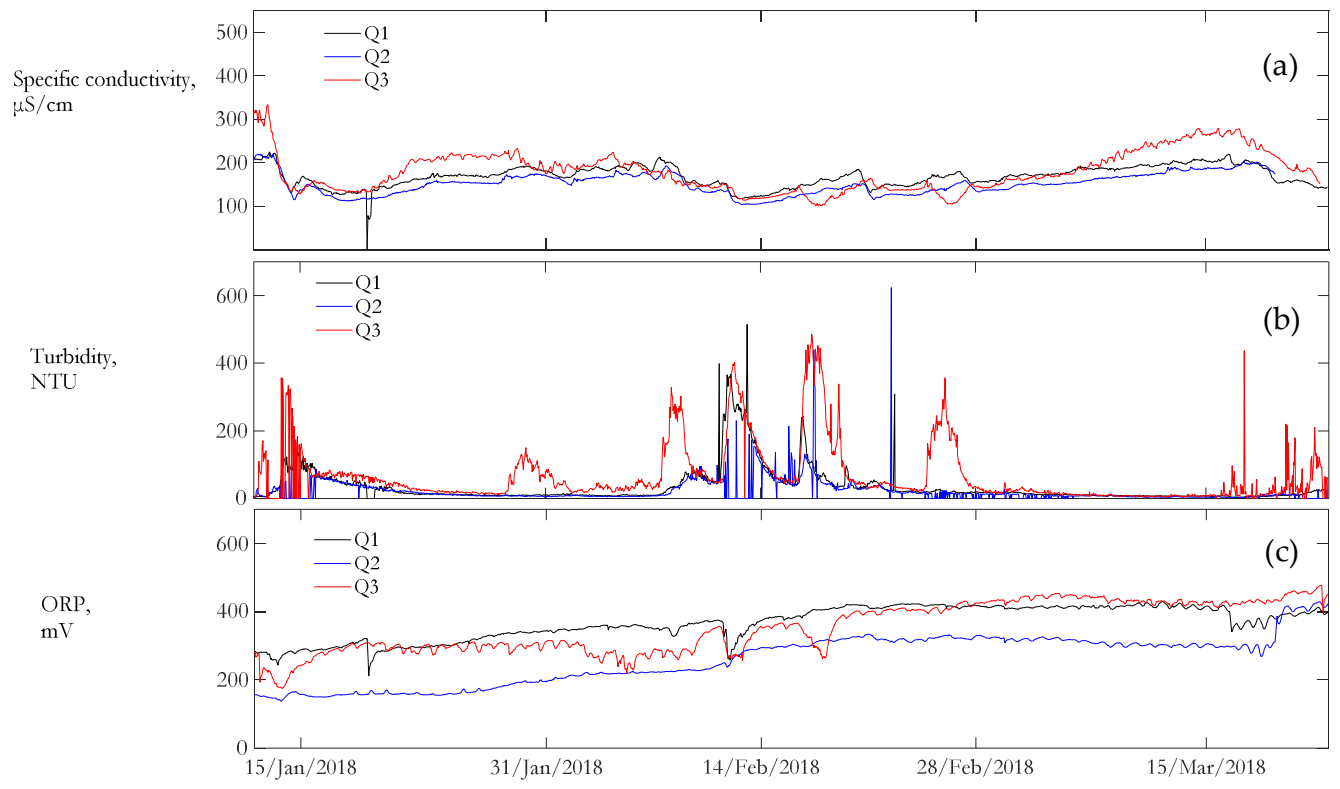

Figure 8. Sensor measurements of (a) specific conductance, (b) turbidity and (c) oxidation-reduction potential (ORP) at three locations (Q1, Q2 and Q3) of the Kanawha River. 
Table 8. Coefficient of variation for water quality measurements from 11 January 2018 to 22 March 2018.

\begin{tabular}{ccccccc}
\hline Location & Temperature & $\begin{array}{c}\text { Dissolved } \\
\text { Oxygen }\end{array}$ & $\begin{array}{c}\text { Dissolved Oxygen } \\
\text { Saturation }\end{array}$ & $\begin{array}{c}\text { Specific } \\
\text { Conductance }\end{array}$ & Turbidity & ORP \\
\hline Q1 & 0.551 & 0.097 & 0.042 & 0.142 & 1.549 & 0.134 \\
Q2 & 0.543 & 0.192 & 0.029 & 0.280 & 1.628 & 0.281 \\
Q3 & 0.529 & 0.304 & 0.030 & 0.266 & 1.311 & 0.208 \\
\hline
\end{tabular}

\subsection{Net Ecosystem Production}

The reaeration rates $(k)$ were calculated using Equations (4)-(6) that consequently helped to estimate NEP through Equation (1). The time series of hydrodynamics (Figure 6) and water quality data (Figure 7) were used at Q1, Q2 and Q3 locations to estimate NEP (Figure 9). Hydrodynamics of the Kanawha River showed higher flows and lower water velocities as water moved downstream, from Q1 to Q2 and to Q3. From water quality monitoring stations (Figure 7), a significant decay of dissolved oxygen and its saturation were observed in Q2 and Q3. For instance, a length of $23.5 \mathrm{~km}$ along the river, the distance between Q1 and Q2, had an average decay from 14.9 to $6.1 \mathrm{mg} / \mathrm{L}$. In the following $29.3 \mathrm{~km}$, the distance between Q2 and Q3, had an additional decay from 6.1 to $4.8 \mathrm{mg} / \mathrm{L}$. Those dissolved oxygen decays reduced the NEP estimations from Q1 to Q2 by 93\% and from Q2 to Q3 by $95 \%$.

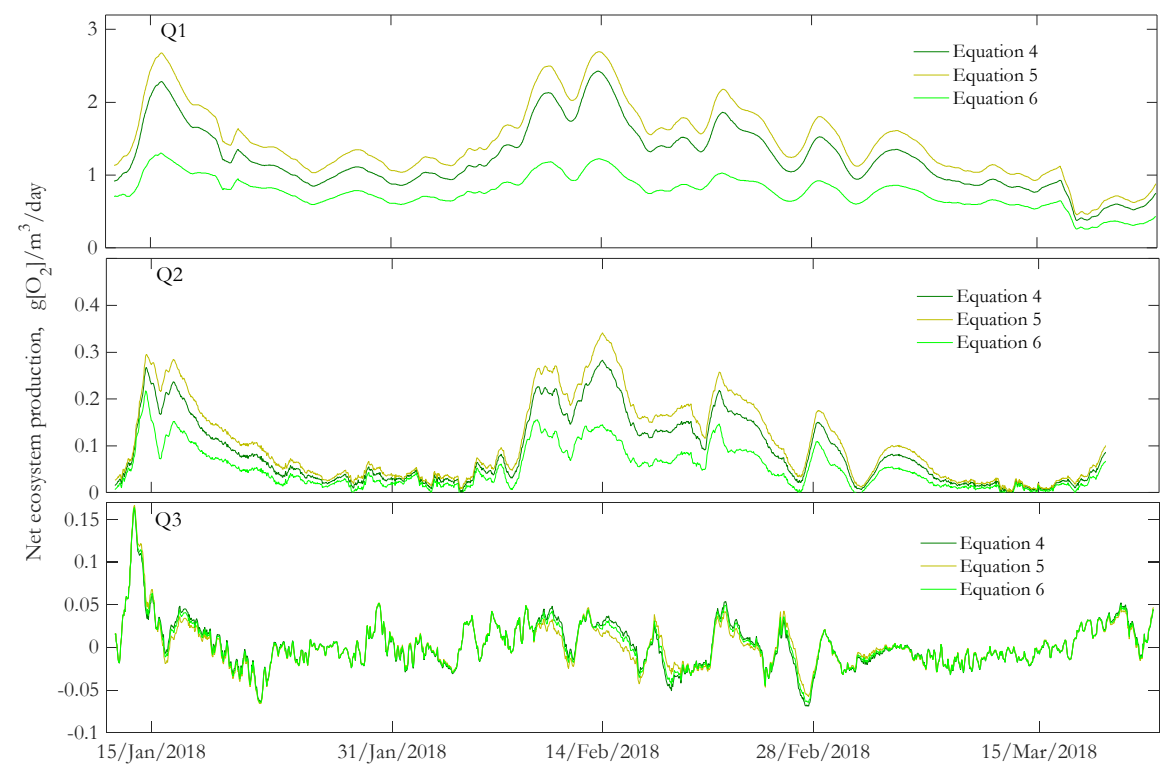

Figure 9. Comparison of the net ecosystem production using Equations (4)-(6) to estimate reaeration rates $k$ at Q1, Q2 and Q3 locations along the Kanawha River, from 11 January 2018 to 22 March 2018.

\subsection{Spatial and Temporal Variability of NEP}

Repeatability and reproducibility are issues around NEP estimations when limited datasets are available in either time or space. These issues frequently happen over sub-daily patterns of dissolved oxygen [46]. In practice, NEP estimations are subjected to periods of observations, the choice of location along the river and the choice of the equation to estimate reaeration rates. Our study provided insight into NEP resolution over space and time based on field surveys and estimating reaeration rates through Equation (4).

For large rivers, either temporal or permanent local gradients may be observed as a result of flow regimes generating specific hydrodynamics $[47,48]$ and consequently variability in NEP. Those NEP estimations will be the consequence of the level of turbulence in local mixing and the exchange rate of gases in the air-water boundary layer [49]. Nonetheless, NEP variability is also a consequence of 
physicochemical properties, such as organic matter [50], nutrient regimes [35], water temperature [51] and flow [10]. Our study conducted a river transect examination of NEP using horizontal and vertical profiles that occur near Q2. The horizontal profile was based on the Q2a and Q2b locations which are separated by $179 \mathrm{~m}$, whereas the vertical profile was based on the Q2b and Q2c locations which are separated by $1.5 \mathrm{~m}$. Three repetitions were conducted at each location, and water velocity was deduced from the HSPF streams module (Table 9). The horizontal profile of NEP was not homogeneous since different conditions were observed in the field; however, there was a prevailing lower NEP in Q2b, which mainly occurred due to water temperature and dissolved oxygen measurements. In contrast, we found that the vertical profile generated lower NEP amounts in Q2c with respect to Q2b, which can be inferred as less prevailing irradiance, as it was $2.5 \mathrm{~m}$ deep. Still, such a discrepancy in NEP at the vertical profile was lower than the horizontal profile as a consequence of the distance between locations. Thus, these findings illustrated that spatial heterogeneity of NEP is driven by transport-reaction phenomena [52] due to local gradients created by hydrodynamics and their corresponding water quality.

Table 9. River transect examination using average net ecosystem production (NEP) with N number of observations.

\begin{tabular}{cccccccc}
\hline Location & Repetition & $\mathbf{N}$ & $\begin{array}{c}\text { Depth, } \\
\mathbf{m}\end{array}$ & $\begin{array}{c}\text { Velocity, } \\
\mathbf{m} / \mathbf{s}\end{array}$ & $\begin{array}{c}\text { Water } \\
\text { Temperature, }{ }^{\circ} \mathbf{C}\end{array}$ & $\begin{array}{c}\text { Dissolved } \\
\text { Oxygen, } \mathbf{m g} / \mathbf{L}\end{array}$ & $\begin{array}{c}\mathbf{N E P} \\
\mathbf{g}\left[\mathbf{O}_{\mathbf{2}}\right] / \mathbf{m}^{3} / \mathbf{d a y}\end{array}$ \\
\hline Q2a & 1 & 36 & 1 & 0.12 & $28.3( \pm 0.9)$ & $8.6( \pm 0.3)$ & 4.3 \\
& 2 & 54 & 1 & 0.08 & $26.7( \pm 1.2)$ & $9.2( \pm 0.5)$ & 3.3 \\
Q2b & 3 & 163 & 1 & 0.05 & $26( \pm 0.5)$ & $8.3( \pm 0.1)$ & 1.7 \\
& 1 & 63 & 1 & 0.11 & $27.8( \pm 0.8)$ & $8.2( \pm 0.2)$ & 1.8 \\
Q2c & 2 & 49 & 1 & 0.08 & $26( \pm 0.5)$ & $8.2( \pm 0.1)$ & 0.9 \\
& 3 & 73 & 1 & 0.05 & $27.3( \pm 1.7)$ & $8.7( \pm 0.3)$ & 1.2 \\
& 1 & 62 & 2.5 & 0.06 & $26.7( \pm 1.5)$ & $8.4( \pm 0.3)$ & 0.8 \\
& 2 & 60 & 2.5 & 0.04 & $26.3( \pm 1.0)$ & $8.4( \pm 0.1)$ & 0.7 \\
\hline
\end{tabular}

NEP in rivers is the result of a dynamic interaction between biotic [53] and abiotic factors [54,55]. Among those biotic factors, autotrophs and heterotrophs are continuously balanced to determine NEP dynamics through the year [56]. Autotrophy impacting NEP along the river is a consequence of nutrient loads from local inflows to the mainstream such as wastewater treatment plants, CSO and NPDES [57]. For instance, it has been found that spatial heterogeneity of NEP can be caused by watersheds comprising urban areas [58]. Our study had an urban area between Q2 and Q3, causing differentiated NEP estimations along the river (Figure 9). A driving variable causing a decay of NEP (Table 10) was dissolved oxygen, which mainly declined due to the various local inflows mixed with the mainstream. It can be interpreted that water residence times of $0.25 \pm 0.03$ days and $0.62 \pm 0.12$ days for the Q1-Q2 and Q2-Q3 river sections, respectively, along with local inflows with different water quality did not help to keep the same NEP estimations as observed in Q1. From our study, we can also claim that the balance between autotrophs and heterotrophs was significantly impaired as water moved downstream. We estimated a decay of $1.18 \pm 0.38 \mathrm{~g}\left[\mathrm{O}_{2}\right] / \mathrm{m}^{3} /$ day from $\mathrm{NEP}_{\mathrm{Q} 1}$ to $\mathrm{NEP}_{\mathrm{Q} 2}$ and an additional decay of $\left.0.08 \pm 0.12 \mathrm{~g} \mathrm{O}_{2}\right] / \mathrm{m}^{3} /$ day from $\mathrm{NEP}_{\mathrm{Q} 2}$ to $\mathrm{NEP}_{\mathrm{Q} 3}$. The latter one was a consequence of prevailing hypoxic conditions observed in Q3.

Table 10. Net ecosystem production (NEP) at three locations of the Kanawha River using N number of observations.

\begin{tabular}{cccccc}
\hline Location & $\mathbf{N}$ & $\begin{array}{c}\text { Velocity, } \\
\mathbf{m} / \mathbf{s}\end{array}$ & $\begin{array}{c}\text { Water } \\
\text { Temperature, }{ }^{\circ} \mathbf{C}\end{array}$ & $\begin{array}{c}\text { Dissolved } \\
\text { Oxygen, } \mathbf{m g} / \mathbf{L}\end{array}$ & $\begin{array}{c}\mathbf{N E P}, \\
\mathbf{g}\left[\mathbf{O}_{\mathbf{2}}\right] / \mathbf{m}^{3} / \text { day }\end{array}$ \\
\hline Q1 & 1682 & $1.11( \pm 0.16)$ & $5.5( \pm 3)$ & $14.9( \pm 1.4)$ & $1.24( \pm 0.4)$ \\
Q2 & 1600 & $0.6( \pm 0.13)$ & $5.4( \pm 3)$ & $6.1( \pm 1.2)$ & $0.09( \pm 0.07)$ \\
Q3 & 1674 & $0.46( \pm 0.11)$ & $5.4( \pm 3)$ & $4.8( \pm 1.5)$ & $0.004( \pm 0.03)$ \\
\hline
\end{tabular}




\subsection{Impact of Water Quality on NEP and Local Inflows}

Additional water quality data were retrieved that can potentially affect NEP dynamics. In particular, the effects of specific conductance [59] and turbidity [60] on NEP were evaluated using the Spearman coefficient. We found through the Spearman coefficient that NEP and turbidity were positive at the three locations along the river (Table 11). We also found that NEP and specific conductance had negative values at the three locations along the river. Nevertheless, it can be deduced that specific conductance and turbidity could play a significant role in determining NEP if the dissolved oxygen measurements do not reach hypoxic conditions.

Table 11. Spearman correlation of net ecosystem production (NEP) with water quality data at three locations of the Kanawha River.

\begin{tabular}{lcc}
\hline & Specific Conductance & Turbidity \\
\hline $\mathrm{NEP}_{\mathrm{Q} 1}$ & -0.61 & 0.81 \\
$\mathrm{NEP}_{\mathrm{Q} 2}$ & -0.57 & 0.41 \\
$\mathrm{NEP}_{\mathrm{Q} 3}$ & -0.01 & 0.06 \\
\hline
\end{tabular}

Because water quality and consequently NEP changed due to local inflows along the river, we computed volumes of aggregated water to the Kanawha River between paired locations $\mathrm{W}_{\mathrm{Q} 1-\mathrm{Q} 2}$ and $\mathrm{W}_{\mathrm{Q} 2-\mathrm{Q} 3}$ as well as their corresponding changes on NEP. We also conducted the same calculations for changes in specific conductance, turbidity and ORP measurements. For the aforementioned calculations, we considered average travel times obtained from the HSPF streams module. Then, Spearman correlations were calculated (Table 12). The segment of the river between Q1 and Q2 showed that $\mathrm{W}_{\mathrm{Q} 1-\mathrm{Q} 2}$ was mainly correlated with NEP and turbidity. For the segment of the river between $\mathrm{Q} 2$ and Q3, we found that $\mathrm{W}_{\mathrm{Q} 2-\mathrm{Q} 3}$ was mainly correlated with specific conductance and NEP. From these correlations, we can state that NEP can be used as an indicator to assess water quality of local inflows, as it merges various properties of the river related to hydrodynamics and water quality data along the river. However, a more reliable assessment could be achieved if hypoxic conditions are avoided.

Table 12. Spearman correlations between local inflows $\left(\mathrm{W}_{\mathrm{Q} 1-\mathrm{Q} 2}\right.$ and $\left.\mathrm{W}_{\mathrm{Q} 2-\mathrm{Q} 3}\right)$ along the Kanawha River and their corresponding changes on the net ecosystem production (NEP), specific conductance, turbidity and ORP.

\begin{tabular}{ccccc}
\hline Local Inflows & NEP & Specific Conductance & Turbidity & ORP \\
\hline $\mathrm{W}_{\mathrm{Q} 1-\mathrm{Q} 2}$ & -0.71 & -0.28 & -0.55 & 0.42 \\
$\mathrm{~W}_{\mathrm{Q} 2-\mathrm{Q} 3}$ & -0.42 & -0.61 & 0.15 & -0.29 \\
\hline
\end{tabular}

\section{Conclusions}

In order to estimate flows along the Kanawha River, our study had to consider a drainage area of $2995 \mathrm{~km}^{2}$. A HSPF model was developed and then calibrated by means of NSGA-II in order to identify the best optimal solution. The streams module of the HSPF model served for hydrodynamic modeling, which provided data about flow and average water velocity at Q1, Q2 and Q3 locations along the Kanawha River. In addition, water quality data were collected for 71 days by placing sondes in the same three locations to hourly log dissolved oxygen concentration, dissolved oxygen saturation, water temperature, specific conductance, turbidity and ORP. Flow and average velocity data were used to estimate reaeration rates $(k)$. Then, $k$ values were used together with water quality data to estimate NEP. It was found that NEP greatly depends on the specific location within the river, as it was observed during a river transect examination. Our study also identified a decreasing NEP as water moved downstream, starting from $\mathrm{NEP}_{\mathrm{Q} 1}$ equal to $1.24( \pm 0.4) \mathrm{g}\left[\mathrm{O}_{2}\right] / \mathrm{m}^{3} /$ day to $\mathrm{NEP}_{\mathrm{Q} 2}$ equal to $0.09( \pm 0.07)$ $\mathrm{g}\left[\mathrm{O}_{2}\right] / \mathrm{m}^{3} /$ day and to $\mathrm{NEP}_{\mathrm{Q} 3}$ equal to $0.004( \pm 0.03) \mathrm{g}\left[\mathrm{O}_{2}\right] / \mathrm{m}^{3} /$ day. Such decay was attributed to local inflows $\left(\mathrm{W}_{\mathrm{Q} 1-\mathrm{Q} 2}\right.$ and $\left.\mathrm{W}_{\mathrm{Q} 2-\mathrm{Q} 3}\right)$, which were computed and correlated with their corresponding changes 
in water quality and NEP. The best Spearman coefficient $(\rho=-0.71)$ was between $W_{\mathrm{Q} 1-\mathrm{Q} 2}$ and NEP. However, under hypoxic conditions, the best Spearman coefficient $(\rho=-0.61)$ was between $\mathrm{W}_{\mathrm{Q} 2-\mathrm{Q} 3}$ and specific conductance. These findings showed that spatial and temporal analyses of NEP were adequately addressed through datasets of hydrology, hydrodynamics and high-frequency data from water quality monitoring stations. Our study can also be useful for further research where assessment of local inflows to the mainstream should be accomplished by means of NEP. These advances encourage us to count more on field surveys, given that the scope of NEP dynamics in rivers depends on multiple scenarios related to flow and water quality conditions.

Supplementary Materials: The Supplementary Data are available online at http://www.mdpi.com/2073-4441/12/ 3/783/s1, Data: water quality data.

Author Contributions: Conceptualization, Software, F.R.; Investigation and Data Curation, D.H.H., I.R.U., V.L.N., A.L.K.-T. and J.E.C.-P.; Writing Original Draft Preparation, Writing-Review and Editing, D.H.H. and F.R. All authors have read and agreed to the published version of the manuscript.

Funding: This research is supported by the National Science Foundation under Award No. OIA-1458952. Any opinions, findings and conclusions, or recommendations expressed in this material are those of the author(s) and do not necessarily reflect the views of the National Science Foundation.

Conflicts of Interest: The authors declare no conflict of interest.

\section{References}

1. Izagirre, O.; Bermejo, M.; Pozo, J.; Elosegi, A. RIVERMET@: An Excel-based tool to calculate river metabolism from diel oxygen-concentration curves. Environ. Model. Softw. 2007, 22, 24-32. [CrossRef]

2. Palmer, M.; Ruhi, A. Linkages between flow regime, biota, and ecosystem processes: Implications for river restoration. Science 2019, 365, eaaw2087. [CrossRef] [PubMed]

3. Uehlinger, $U$. Annual cycle and inter-annual variability of gross primary production and ecosystem respiration in a floodprone river during a 15-year period. Freshw. Biol. 2006, 51, 938-950. [CrossRef]

4. Savoy, P.; Appling, A.P.; Heffernan, J.B.; Stets, E.G.; Read, J.S.; Harvey, J.W.; Bernhardt, E.S. Metabolic rhythms in flowing waters: An approach for classifying river productivity regimes. Limnol. Oceanogr. 2019, 64, 1835-1851. [CrossRef]

5. Odum, H.T. Primary production in flowing waters. Limnol. Oceanogr. 1956, 1, 102-117. [CrossRef]

6. Staehr, P.A.; Testa, J.M.; Kemp, W.M.; Cole, J.J.; Sand-Jensen, K.; Smith, S.V. The metabolism of aquatic ecosystems: History, applications, and future challenges. Aquat. Sci. 2012, 74, 15-29. [CrossRef]

7. Staehr, P.A.; Bade, D.; Van de Bogert, M.C.; Koch, G.R.; Williamson, C.; Hanson, P.; Cole, J.J.; Kratz, T. Lake metabolism and the diel oxygen technique: State of the science. Limnol. Oceonogr. Methods 2010, 8, 628-644. [CrossRef]

8. Lovett, G.M.; Cole, J.J.; Pace, M.L. Is net ecosystem production equal to ecosystem carbon accumulation? Ecosystems 2006, 9, 152-155. [CrossRef]

9. Hall, R.O.; Tank, J.L.; Baker, M.A.; Rosi-Marshall, E.J.; Hotchkiss, E.R. Metabolism, Gas Exchange, and Carbon Spiraling in Rivers. Ecosystems 2016, 19, 73-86. [CrossRef]

10. Mejia, F.H.; Fremier, A.K.; Benjamin, J.R.; Bellmore, J.R.; Grimm, A.Z.; Watson, G.A.; Newsom, M. Stream metabolism increases with drainage area and peaks asynchronously across a stream network. Aquat. Sci. 2019, 81, 1-17. [CrossRef]

11. Beaulieu, J.J.; Arango, C.P.; Balz, D.A.; Shuster, W.D. Continuous monitoring reveals multiple controls on ecosystem metabolism in a suburban stream. Freshw. Biol. 2013, 58, 918-937. [CrossRef]

12. Blersch, S.S.; Blersch, D.M.; Atkinson, J.F. Metabolic Variance: A Metric to Detect Shifts in Stream Ecosystem Function as a Result of Stream Restoration. J. Am. Water Resour. Assoc. 2019, 55, 608-621. [CrossRef]

13. Duda, P.B.; Hummel, P.R.; Donigian, A.S., Jr.; Imhoff, J.C. BASINS/HSPF: Model Use, Calibration, and Validation. Trans. ASABE 2012, 55, 1523-1547. [CrossRef]

14. Chen, W.; He, B.; Nover, D.; Duan, W.; Luo, C.; Zhao, K.; Chen, W. Spatiotemporal patterns and source attribution of nitrogen pollution in a typical headwater agricultural watershed in Southeastern China. Environ. Sci. Pollut. Res. 2018, 25, 2756-2773. [CrossRef] [PubMed] 
15. Fu, B.; Merritt, W.S.; Croke, B.F.W.; Weber, T.R.; Jakeman, A.J. A review of catchment-scale water quality and erosion models and a synthesis of future prospects. Environ. Model. Softw. 2019, 114, 75-97. [CrossRef]

16. Wagena, M.B.; Collick, A.S.; Ross, A.C.; Najjar, R.G.; Rau, B.; Sommerlot, A.R.; Fuka, D.R.; Kleinman, P.J.A.; Easton, Z.M. Impact of climate change and climate anomalies on hydrologic and biogeochemical processes in an agricultural catchment of the Chesapeake Bay watershed, USA. Sci. Total. Environ. 2018, 637, 1443-1454. [CrossRef]

17. Deb, K.; Pratap, A.; Agarwal, S.; Meyarivan, T. A fast and elitist multiobjective genetic algorithm: NSGA-II. IEEE Trans. Evol. Comput. 2002, 6, 182-197. [CrossRef]

18. Panagopoulos, Y.; Makropoulos, C.; Kossida, M.; Mimikou, M. Optimal implementation of irrigation practices: Cost-effective desertification action plan for the Pinios basin. J. Water Resour. Plan. Manag. 2014, 140, 05014005. [CrossRef]

19. Hassanzadeh, Y.; Afshar, A.A.; Pourreza-Bilondi, M.; Memarian, H.; Besalatpour, A.A. Toward a combined Bayesian frameworks to quantify parameter uncertainty in a large mountainous catchment with high spatial variability. Environ. Monit. Assess. 2019, 191,1-22. [CrossRef]

20. Xie, H.; Shen, Z.; Chen, L.; Lai, X.; Qiu, J.; Wei, G.; Dong, J.; Peng, Y.; Chen, X. Parameter estimation and uncertainty analysis: A comparison between continuous and event-based modeling of streamflow based on the Hydrological Simulation Program-Fortran (HSPF) model. Water 2019, 11, 171. [CrossRef]

21. Zhang, R.; Moreira, M.; Corte-Real, J. Multi-objective calibration of the physically based, spatially distributed SHETRAN hydrological model. J. Hydroinform. 2015, 18, 428-445. [CrossRef]

22. Dumedah, G.; Berg, A.A.; Wineberg, M.; Collier, R. Selecting Model Parameter Sets from a Trade-off Surface Generated from the Non-Dominated Sorting Genetic Algorithm-II. Water Resour. Manag. 2010, 24, 4469-4489. [CrossRef]

23. Mostafaie, A.; Forootan, E.; Safari, A.; Schumacher, M. Comparing multi-objective optimization techniques to calibrate a conceptual hydrological model using in situ runoff and daily GRACE data. Comput. Geosci. 2018, 22, 789-814. [CrossRef]

24. Lampert, D.J.; Wu, M. Development of an open-source software package for watershed modeling with the Hydrological Simulation Program in Fortran. Environ. Model. Softw. 2015, 68, 166-174. [CrossRef]

25. Raymond, P.A.; Zappa, C.J.; Butman, D.; Bott, T.L.; Potter, J.; Mulholland, P.; Laursen, A.E.; McDowell, W.H.; Newbold, D. Scaling the gas transfer velocity and hydraulic geometry in streams and small rivers. Limnol. Oceanogr. Fluids Environ. 2012, 2, 41-53. [CrossRef]

26. Hall, R.O.; Ulseth, A.J. Gas Exchange in Streams and Rivers. WIREs Water 2019, 1-18. [CrossRef]

27. Zappa, C.J.; McGillis, W.R.; Raymond, P.A.; Edson, J.B.; Hintsa, E.J.; Zemmelink, H.J.; Dacey, J.W.H.; Ho, D.T. Environmental turbulent mixing controls on air-water gas exchange in marine and aquatic systems. Geophys. Res. Lett. 2007, 34, 1-6. [CrossRef]

28. Wanninkhof, R. Relationship between wind speed and gas exchange over the ocean revisited. Limnol. Oceanogr. Methods 2014, 12, 351-362. [CrossRef]

29. Hill, N.B.; Riha, S.J.; Walter, M.T. Temperature dependence of daily respiration and reaeration rates during baseflow conditions in a northeastern U.S. stream. J. Hydrol. Reg. Stud. 2018, 19, 250-264. [CrossRef]

30. Engel, F.; Attermeyer, K.; Ayala, A.I.; Fischer, H.; Kirchesch, V.; Pierson, D.C.; Weyhenmeyer, G.A. Phytoplankton gross primary production increases along cascading impoundments in a temperate, lowdischarge river: Insights from high frequency water quality monitoring. Sci. Rep. 2019, 9, 1-13. [CrossRef]

31. Bernhardt, E.S.; Heffernan, J.B.; Grimm, N.B.; Stanley, E.H.; Harvey, J.W.; Arroita, M.; Appling, A.P.; Cohen, M.J.; McDowell, W.H.; Hall, R.O.; et al. The metabolic regimes of flowing waters. Limnol. Oceanogr. 2018, 63, S99-S118. [CrossRef]

32. Demars, B.O.L.; Thompson, J.; Manson, J.R. Stream metabolism and the open diel oxygen method: Principles, practice, and perspectives. Limnol. Oceanogr. Methods 2015, 13, 356-374. [CrossRef]

33. Mansoor, S.Z.; Louie, S.; Lima, A.T.; Van Cappellen, P.; MacVicar, B. The spatial and temporal distribution of metals in an urban stream: A case study of the Don River in Toronto, Canada. J. Great Lakes Res. 2018, 44, 1314-1326. [CrossRef]

34. Abdul-Aziz, O.I.; Ahmed, S. Relative linkages of stream water quality and environmental health with the land use and hydrologic drivers in the coastal-urban watersheds of southeast Florida. GeoHealth 2017, 1, 180-195. [CrossRef] 
35. Fuß, T.; Behounek, B.; Ulseth, A.J.; Singer, G.A. Land use controls stream ecosystem metabolism by shifting dissolved organic matter and nutrient regimes. Freshw. Biol. 2017, 62, 582-599. [CrossRef]

36. O'Brien, J.M.; Warburton, H.J.; Elizabeth Graham, S.; Franklin, H.M.; Febria, C.M.; Hogsden, K.L.; Harding, J.S.; McIntosh, A.R. Leaf litter additions enhance stream metabolism, denitrification, and restoration prospects for agricultural catchments. Ecosphere 2017, 8, 1-17. [CrossRef]

37. Griffiths, N.A.; Tank, J.L.; Royer, T.V.; Roley, S.S.; Rosi-Marshall, E.J.; Whiles, M.R.; Beaulieu, J.J.; Johnson, L.T. Agricultural land use alters the seasonality and magnitude of stream metabolism. Limnol. Oceanogr. 2013, 58, 1513-1529. [CrossRef]

38. National Solar Radiation Database. Available online: https://nsrdb.nrel.gov (accessed on 27 May 2019).

39. Berndt, M.E.; Rutelonis, W.; Regan, C.P. A comparison of results from a hydrologic transport model (HSPF) with distributions of sulfate and mercury in a mine-impacted watershed in northeastern Minnesota. J. Environ. Manag. 2016, 181, 74-79. [CrossRef]

40. Bello, A.A.D.; Haniffah, M.R.M.; Hanapi, M.N.; Usman, A.B. Identification of critical source areas under present and projected land use for effective management of diffuse pollutants in an urbanized watershed. Int. J. River Basin Manag. 2019, 17, 171-184. [CrossRef]

41. Borah, D.K.; Bera, M. Watershed-Scale Hydrologic and Nonpoint-Source Pollution Models: Review of Applications. Trans. ASAE 2013, 47, 789-803. [CrossRef]

42. Nash, J.E.; Sutcliffe, J.V. River flow forecasting through conceptual models part I-A discussion of principles. J. Hydrol. 1970, 10, 282-290. [CrossRef]

43. Moriasi, D.N.; Arnold, J.G.; Van Liew, M.W.; Bingner, R.L.; Harmel, R.D.; Veith, T.L. Model evaluation guidelines for systematic quantification of accuracy in watershed simulations. Am. Soc. Agric. Biol. Eng. 2007, 50, 885-900.

44. Pandey, P.K.; Dabral, P.P.; Pandey, V. Evaluation of reference evapotranspiration methods for the northeastern region of India. Int. Soil Water Conserv. Res. 2016, 4, 52-63. [CrossRef]

45. Huber, D.H.; Ugwuanyi, I.R.; Lhilhi, N.V.; Kemajou, T.; Andrielle, L.; Chavarria-Palma, J.E. Water Quality for Kanawha River WV. Available online: https:/doi.org/10.6084/m9.figshare.9786212.v1 (accessed on 22 September 2019).

46. Appling, A.P.; Hall, R.O.; Yackulic, C.B.; Arroita, M. Overcoming Equifinality: Leveraging Long Time Series for Stream Metabolism Estimation. J. Geophys. Res. Biogeosci. 2018, 123, 624-645. [CrossRef]

47. Tang, G.; Zhu, Y.; Wu, G.; Li, J.; Li, Z.L.; Sun, J. Modelling and analysis of hydrodynamics and water quality for rivers in the northern cold Region of China. Int. J. Environ. Res. Public Health 2016, 13, 408. [CrossRef]

48. Falkowski, T.; Ostrowski, P.; Siwicki, P.; Brach, M. Channel morphology changes and their relationship to valley bottom geology and human interventions; a case study from the Vistula Valley in Warsaw, Poland. Geomorphology 2017, 297, 100-111. [CrossRef]

49. Read, J.S.; Hamilton, D.P.; Desai, A.R.; Rose, K.C.; MacIntyre, S.; Lenters, J.D.; Smyth, R.L.; Hanson, P.C.; Cole, J.J.; Staehr, P.A.; et al. Lake-size dependency of wind shear and convection as controls on gas exchange. Geophys. Res. Lett. 2012, 39, 1-5. [CrossRef]

50. Halbedel, S.; Büttner, O.; Weitere, M. Linkage between the temporal and spatial variability of dissolved organic matter and whole-stream metabolism. Biogeosciences 2013, 10, 5555-5569. [CrossRef]

51. Demars, B.O.L.; Russell, M.J.; Ólafsson, J.S.; Gíslason, G.M.; Gudmundsdóttir, R.; Woodward, G.; Reiss, J.; Pichler, D.E.; Rasmussen, J.J.; Friberg, N. Temperature and the metabolic balance of streams. Freshw. Biol. 2011, 56, 1106-1121. [CrossRef]

52. Reichert, P.; Uehlinger, U.; Acuña, V. Estimating stream metabolism from oxygen concentrations: Effect of spatial heterogeneity. J. Geophys. Res. Biogeosci. 2009, 114, 1-15. [CrossRef]

53. Huber, D.H.; Ugwuanyi, I.R.; Malkaram, S.A.; Montenegro-Garcia, N.A.; Lhilhi, N.V.; Chavarria-Palma, J.E. Metagenome Sequences of Sediment from a Recovering Industrialized Appalachian River in West Virginia. Genome Announc. 2018, 6, e00350-18. [CrossRef] [PubMed]

54. Bernot, M.J.; Sobota, D.J.; Hall, R.O.; Mulholland, P.J.; Dodds, W.K.; Webster, J.R.; Tank, J.L.; Ashkenas, L.R.; Cooper, L.W.; Dahm, C.N.; et al. Inter-regional comparison of land-use effects on stream metabolism. Freshw. Biol. 2010, 55, 1874-1890. [CrossRef]

55. Uehlinger, U.; Kawecka, B.; Robinson, C.T. Effects of experimental floods on periphyton and stream metabolism below a high dam in the Swiss Alps (River Spöl). Aquat. Sci. 2003, 65, 199-209. [CrossRef] 
56. Izagirre, O.; Agirre, U.; Bermejo, M.; Pozo, J.; Elosegi, A. Environmental controls of whole-stream metabolism identified from continuous monitoring of Basque streams. J. N. Am. Benthol. Soc. 2008, 27, 252-268. [CrossRef]

57. Sánchez-Pérez, J.M.; Gerino, M.; Sauvage, S.; Dumas, P.; Maneux, É.; Julien, F.; Winterton, P.; Vervier, P. Effects of wastewater Treatment Plant pollution on in-stream ecosystems functions in an agricultural watershed. Ann. Limnol. 2009, 45, 79-92. [CrossRef]

58. Kaushal, S.S.; Delaney-Newcomb, K.; Findlay, S.E.G.; Newcomer, T.A.; Duan, S.; Pennino, M.J.; Sivirichi, G.M.; Sides-Raley, A.M.; Walbridge, M.R.; Belt, K.T. Longitudinal patterns in carbon and nitrogen fluxes and stream metabolism along an urban watershed continuum. Biogeochemistry 2014, 121, 23-44. [CrossRef]

59. Grace, M.R.; Giling, D.P.; Hladyz, S.; Caron, V.; Thompson, R.M.; Mac Nally, R. Fast processing of diel oxygen curves: Estimating stream metabolism with base (BAyesian single-station estimation). Limnol. Oceanogr. Methods 2015, 13, 103-114. [CrossRef]

60. Tang, S.; Sun, T.; Shen, X.M.; Qi, M.; Feng, M.L. Modeling net ecosystem metabolism influenced by artificial hydrological regulation: AN application to the Yellow River Estuary, China. Ecol. Eng. 2015, 76, 84-94. [CrossRef]

(C) 2020 by the authors. Licensee MDPI, Basel, Switzerland. This article is an open access article distributed under the terms and conditions of the Creative Commons Attribution (CC BY) license (http://creativecommons.org/licenses/by/4.0/). 